\title{
INTERVENSI KEPERAWATAN PADA ORANGTUA BBLR DALAM UPAYA MENGATASI ANSIETAS ORANGTUA MELALUI PEMBERDAYAAN ORANG TUA
}

\author{
Qurrotul Aeni*, Novi Indrayati, Dwi Haryanti, Istioningsih \\ Program Studi Ilmu Keperawatan, Sekolah Tinggi Ilmu Kesehatan Kendal \\ *qurrotul80@gmail.com
}

\begin{abstract}
ABSTRAK
Bayi berat lahir rendah atau BBLR adalah bayi yang lahir dengan berat badan lahir kurang dari 2.500 gram tanpa memandang masa kehamilan. Kondisi BBLR dan kebutuhan bayi akan perawatan khusus, dapat menimbulkan gangguan psikologis bagi bayi dan orangtua, hal ini terjadi karena secara psikologis orang tua belum siap untuk menghadapi kondisi bayinya. Kelahiran BBLR dan perawatan bayi diruang intensive merupakan kejadian yang tidak diharapkan orangtua dan dapat menimbulkan kecemasan. Tujuan penelitian ini adalah untuk membuktikan keefektifan intervensi keperawatan dalam mengatasi ansietas orangtua yang memiliki BBLR melalui pemberdayaan orangtua (parent empowerment). Jenis penelitian yang gunakan pada penelitian ini adalah quasi eksperimen dengan pre post test without control group. Populasi dan sampel dalam penelitian ini adalah semua orangtua yang memiliki bayi BBLR dengan jumlah 40 orangtua dengan menggunakan teknik total accidental. Alat ukur penelitian yang digunakan pada penelitian ini untuk mengukur ansietas orangtua dengan kuesioner Depression Anxiety Stress Scale yang terdiri 14 pertanyaan terkait ansietas, dikembangkan oleh Lovibond pada tahun 1995 dengan dengan hasil uji cronbach alpha 0.9483. Analisis univariat pada penelitian ini menggunakan distribusi frekuensi, sedangkan analisis bivariat menggunakan uji Wilcoxon. Hasil analisis uji statistik didapatkan $p$ value 0,016, hal ini menunjukan bahwa ada perbedaan tingkat ansietas orangtua yang mempunyai BBLR di ruang Perinatologi RS Se-Kabupaten Kendal sebelum dan sesudah pemberdayaan orangtua
\end{abstract}

Kata kunci: ansietas, BBLR, perberdayaan orangtua

\section{NURSING INTERVENTION OF LBW IN EFFORT TO OVERCOME ANXIETY OF PARENTS THROUGH EMPOWERMENT OF PARENTS}

\begin{abstract}
Low birth weight babies or $L B W$ are babies born with birth weight less than 2,500 grams regardless of pregnancy. $L B W$ conditions and the baby's need for special care, can cause psychological disorders for babies and parents, this happens because psychologically parents are not ready to deal with the condition of their babies. LBW births and baby care in the intensive room are events that are not expected by parents and can cause anxiety. The purpose of this study is to prove the effectiveness of nursing interventions in overcoming anxiety (anxiety) of parents who have LBW through parent empowerment. This type of research used in this study is a quasi-experimental with pre-post test without control group. The population and sample in this study were all parents who had LBW babies with a total of 40 parents using total accidental sampling techniques. The research measuring instrument used in this study to measure parental anxiety is the DASS (Depression Anxiety Stress Scale) questionnaire consisting of 14 anxiety-related questions developed by Lovibond in 1995 with the results of the Cronbach alpha 0.9483 test. The univariate analysis in this study uses the frequency distribution, while the bivariate analysis uses the Wilcoxon test. The results of the statistical test analysis obtained $P$ value 0.016, this shows that there are differences in the level of anxiety of parents who have LBW in the Perinatology Room of Kendal District Hospital before and after parent empowerment.
\end{abstract}

Keywords: anxiety, low birth weigh, parent empowerment

\section{PENDAHULUAN}

Bayi berat lahir rendah (BBLR) adalah bayi yang lahir dengan berat badan lahir kurang dari 2.500 gram tanpa memandang masa kehamilan (Wong, Hockenberry-Eaton, Wilson,
Winkelstein, \& Schwartz, 2009). BBLR menjadi penyebab kematian nomor dua pada neonatal dini yaitu sebesar 32,3\% (Departemen Kesehatan R.I., 2008). Kondisi BBLR dan kebutuhan bayi akan perawatan khusus, 
merupakan pengalaman stres, cemas dan depresi bagi orangtua (Cleveland, 2008). Hal ini terjadi karena secara psikologis orang tua belum siap untuk menghadapi kondisi bayinya. Penelitian yang akan dilakukan bertujuan untuk membuktikan keefektifan intervensi keperawatan untuk mengatasi anxietas (kecemasan) orang tua yang memiliki BBLR melalui pemberdayaan orang tua.

BBLR memiliki sistem organ yang belum matang sehingga kesulitan untuk beradaptasi dengan lingkungan. BBLR memerlukan perawatan intensif di ruang perawatan khusus seperti ruang perinatologi dan Neonatal Intensive Care Unit (NICU) yang memerlukan waktu yang cukup lama (Mundy, 2010). Partisipasi orang tua dalam perawatan BBLR sangat berdampak pada kualitas dan pertahanan hidup BBLR, mencegah angka kejadian infeksi, malnutrisi dan kematian pada BBLR (Girsang, 2009).

Kelahiran BBLR dan perawatan bayi diruang intensive merupakan kejadian yang tidak diharapkan dan dapat menimbulkan kecemasan. Stressor orangtua berawal dari perpisahan dengan bayinya yang baru lahir; ketidakmampuan untuk menjaga, dan merawat bayi; ketidakmampuan melindungi bayi dari nyeri; penggunaan teknologi serta alat-alat di ruang intensif; dan kritisnya kondisi bayi (Mundy, 2010). Penelitian menunjukkan 50\% ibu yang mempunyai bayi BBLR yang dirawat di ruang perinatologi mengalami tingkat kecemasan sedang, $31,2 \%$ mengalami kecemasan berat dan $18,8 \%$ mengalami kecemasan ringan (Wahyu Hendiyanto, 2014). Kecemasan yang dialami orang tua dapat mempengaruhi kondisi BBLR. ada hubungan yang signifikan antara rawat inap (hospitalisasi) dengan kecemasan orang tua. Rasa cemas orang tua dapat menghambat proses perawatan bayi BBLR (Dyna Apryani, 2013).

Kecemasan orang tua terhadap permasalahan BBLR sangat mempengaruhi keputusan orang tua untuk melakukan perawatan terhadap bayinya (Surasmi, 2003). Oleh karena itu, kecemasan yang dialami orangtua perlu diatasi. Salah satu prinsip Family Center Care (FCC) yaitu pemberdayaan (Empowerment) keluarga dapat digunakan untuk meminimalkan kecemasan orangtua akibat kondisi dan perawatan BBLR. Pemberdayaan orang tua bertujuan untuk meningkatkan pemahaman orang tua, menemukan kekuatan diri, menumbuhkan rasa percaya diri dan menentukan pilihan dan keputusan orang tua dalam perawatan BBLR.

Berdasarkan studi pendahuluan yang dilakukan pada tanggal 4 dan 5 Januari 2017, menggunakan alat ukur kuesioner DASS 42 dengan 7 orangtua BBLR di ruang Perinatologi se-Kabupaten Kendal tentang tingkat orangtua dengan bayi BBLR didapatkan hasil 5 dari orang tua tersebut mengalami ansietas sedang, dan 2 mengalami ansietas ringan. Adapun rata-rata jumlah bayi BBLR di ruang prinatologi selama 3 bulan terakhir mulai Oktober - Desember 2017 sebanyak 40 bayi. Orangtua memiliki peran penting dalam keperawatan anak, perawat perlu melibatkan orangtua dalam perawatan anak agar terjalin hubungan antara orangtua dan anak. Masalah pada BBLR adalah perpisahan antara orangtua dengan bayi yang harus dirawat di Ruang NICU, dan frekuensi pertemuan antara orangtua dan bayi tidak dapat terjadi secara terus menerus. Keadaan BBLR yang berbeda dengan kondisi bayi pada normalnya membuat orangtua merasa cemas. Setiap keluarga memiliki kemampuan masingmasing, peneliti ingin menganalisis dengan pemberdayaan orangtua (parent empowerment) apakah dapat mengatasi ansietas pada orangtua yang memiliki BBLR.

\section{METODE}

Desain penelitian pada penelitian ini adalah quasi eksperimen dengan pre post test without control group. Populasi dan sampel dalam penelitian ini adalah semua orangtua yang memiliki bayi BBLR dengan jumlah 40 orangtua dengan menggunakan menggunakan teknik pengambilan sampel secara total accidental. Alat ukur penelitian yang digunakan pada penelitian ini untuk mengukur ansietas orangtua adalah dengan kuesioner DASS (Depression Anxiety Stress Scale) yang terdiri 14 pertanyaan terkait ansietas yang dikembangkan oleh Lovibond pada tahun 1995 dengan dengan hasil uji cronbach alpha 0.9483. peneliti mengumpulkan data pre test untuk mengukur tingkat ansietas responden dengan cara memberikan kuesioner kepada responden untuk diisi sebelum responden diberdayakan, setelah itu diukur kembali tingkat ansietas responden dengan menggunakan DASS. Peneliti menjaga rahasia responden dengan cara tidak menampilkan identitas responden namun menggunakan 
kode. Analisis univariat pada penelitian ini menggunakan distribusi frekuensi, sedangkan analisis bivariat menggunakan uji Wilcoxon

\section{HASIL}

Tabel 1. Menunjukan ada beberapa karasteristik responden yang diteliti yaitu pendidikan, jenis kelamin, anak yang dimiliki, usia, penghasilan dan pekerjaan. Hasil analis menggunakan analisis univariat dengan distribusi frekuensi dapat dilihat bahwa sebagaian besar responden dalam penelitian ini berpendidikan SLTA yaitu sebanyak 15 responden (37,5\%), seluruh responden berjenis kelamin perempuan (100\%), dengan mayoritas usia responden tergolong dewasa yaitu sebanyak 31 (77,5\%), anak yang dimiliki responden, mayoritas bukan anak pertama yaitu 25 responden atau $62,5 \%$ reponden, sebagian besar responden tidak bekerja yaitu ada 21 responden (52,5\%) dan ada 24 responden atau sebanyak $60 \%$ responden berpenghasilan dibawah UMK.

Tabel 1.

Karakteristik responden $(n=40)$

\begin{tabular}{lcc}
\hline Variabel & f & $\%$ \\
\hline Pendidikan & 13 & 32,5 \\
$\quad$ SD & 11 & 27,5 \\
SLTP & 15 & 37,5 \\
SLTA & 1 & 2,5 \\
$\quad$ Perguruan Tinggi & 0 & \\
\hline Jenis Kelamin & 40 & 0 \\
$\quad$ Laki-laki & & 100 \\
$\quad$ Perempuan & 15 & 37,5 \\
\hline Anak Yang dimiliki & 25 & 62,5 \\
$\quad$ Anak pertama & & \\
$\quad$ Bukan anak pertama & 9 & 22,5 \\
Usia & 31 & 77,5 \\
$\quad$ Dewasa Muda & & \\
Dewasa & 24 & 60 \\
\hline Penghasilan & 16 & 40 \\
$\quad$ UMK & & \\
$\quad$ UMK & 21 & 52,5 \\
\hline Pekerjaan & 19 & 47,5 \\
$\quad$ Tidak bekerja & & \\
$\quad$ Bekerja &
\end{tabular}

Tabel 2.

Ansietas Orangtua BBLR sebelum dan setelah diberikan intervensi $(\mathrm{n}=40)$

\begin{tabular}{lcc}
\hline Ansietas Orangtua & $\mathrm{f}$ & $\%$ \\
\hline Sebelum diberikan intervensi & 33 & 82,5 \\
Ansietas Normal & 3 & 7,5 \\
Ansietas Ringan & 2 & 5,0 \\
Ansietas Sedang & 1 & 2,5 \\
Ansietas Berat & 1 & 2,5 \\
Ansietas Sangat Berat & & \\
\hline Sesudah diberikan intervensi & 39 & 97,5 \\
Ansietas Normal & 1 & 2,5 \\
Ansietas Sedang &
\end{tabular}

Tabel 3 .

Pengaruh intervensi keperawatan pada orangtua BBLR pre test dan post tes $(\mathrm{n}=40)$

\begin{tabular}{llll}
\hline Variabel & $\mathrm{n}$ & \multicolumn{2}{c}{ Nilai P-Value } \\
\hline Ansietas orangtua sebelum intervensi & 40 & 0,016 \\
\hline Tabel 2 menunjukkan bahwa mayoritas & ruang & perinatologi, & sebelum diberikan \\
orangtua yang memiliki BBLR dan dirawat di & intervensi mengalami & ansietas normal yaitu
\end{tabular}


sebanyak 33 responden atau sebanyak 82,5\%, sesudah diberikan intervensi, ansietas normal menjadi 39 responden $(97,5 \%)$.

Tabel 3 menunjukkan bahwa hasil uji statisik diperoleh nilai P-Value 0,016 , hal ini memiliki makna bahwa ada perbedaan tingkat ansietas orangtua yang mempunyai BBLR di ruang Perinatologi RS Se-Kabupaten Kendal sebelum dan sesudah intervensi.

\section{PEMBAHASAN}

Hasil penelitian ini menunjukkan bahawa terdapat perbedaan tingkat ansietas orangtua yang mempunyai BBLR di ruang Perinatologi RS Se-Kabupaten Kendal sebelum dan sesudah pemberdayaan orangtua (parent empowerment), hasil ini didukung oleh penelitian Suyami (2013) tentang Pengaruh edukasi terhadap tingkat

kecemasan dan tingkat efikasi diri ibu dalam merawat BBLR di dapatkan hasil Tingkat kecemasan dan efikasi diri pada kelompok intervensi terdapat perbedaan yang bermakna. Sedangkan pada kelompok kontrol tidak terdapat perbedaan yang bermakna. Kecemasan berhubungan dengan pendapat dan pengalaman $(p<0,05)$, sedangkan efikasi diri berhubungan dengan pendapat, pengalaman, dan jumlah anak $(\mathrm{p}<0,05)$. Kesimpulan bahwa edukasi memandikan dan perawatan metode kanguru efektif menurunkan kecemasan dan meningkatkan efikasi diri. Rekomendasi edukasi dapat diberikan pada ibu dengan bayi berat lahir rendah (Suyami, 2013).

BBLR memerlukan perawatan lebih intensif, penatalaksanaan segera setelah lahir yang mencakup dukungan respirasi, kehangatan, dan pencegahan infeksi memegang peranan penting dalam memfasilitasi proses adaptasi bayi. BBLR juga mempunyai risiko untuk mengalami keterlambatan dalam pertumbuhan dan perkembangannya (Dyna Apryani, 2013), Oleh sebab itu BBLR harus mendapatkan asuhan keperawatan yang komprehensif di ruangan khusus yang tidak saja memperhatikan aspek fisiknya, tetapi juga aspek psikologis. Peran orangtua sangat penting dalam perawatan bayi BBLR, ketidak pastian akan kondisi dan perawatan medis abyi BBLR sering membuat orangua mengalami stress dan kecemasan. $75,56 \%$ orangtua bayi BBLR memiliki pengetahuan kurang dalam mempertahankan suhu dan kehangatan,
$44,45 \%$ kurang tahu dalam pencegahan infeksi pada bayi BBLR dan hanya $42,22 \%$ orangtua yang memiliki pengetahuan cukup dalam memberikan ASI pada bayi BBLR (Rita Magdalena br. Tarigan, Restuning Widiasih, 2008)

Hasil studi pendahuluan yang dilakukan oleh Padila dalam penelitiannya tentang pengalaman ibu dalam merawat bayi preterm, salah satu partisipan yang memiliki bayi preterm, menceritakan pengalaman pertama kali ketika mengetahui bahwa bayinya preterm menyatakan bahwa " terkejut, syok dan panik, menangis dan bingung", karena seluruh badan anaknya berwarna biru, dan susah bernafas, ibu pikiranaknya tidak akan selamat. Partisipan yang lainnya menyatakan bahwa kecemasannya semakin tinggi ketika tidak mengetahui keadaan anaknya setelah persalinan selesai, karena pihak keluarga tidak memberikan izin kepada petugas medis untuk memberi informasi kepada klien, jika anaknya lahir dengan keadaan berat badan kurang dari 2500 gram (Padila, Amin, \& Rizki, 2018)

Orangtua yang memiliki bayi berat lahir rendah sering mengalami masalah adaptasi, mereka akan memerlukan asuhan keperawatan yang sensitif dan seksama, hal ini di karenakan orangtua yang memiliki bayi berat lahir rendah tidak hanya menghadapi masa transisi menjadi orang tua dengan segala kebutuhannya, tetapi mereka juga harus menghadapi situasi yang berbeda. BBLR biasanya berukuran kecil dan sering sakit. Pembentukan ikatan antara orang tua dan bayi baru lahir serta penetapan landasan sikap yang sehat demi hubungan mereka di masa yang akan datang dirasa perlu untuk diperhatikan (Reeder, S. J., \& Griffin, 2011).

Pemberdayaan orang tua meliputi: peningkatan pengetahuan, ketrampilan dan partisipasi orangtua dalam perawatan BBLR bertujuan untuk meningkatkan pemahaman orang tua melalui edukasi tentang penyakit dan keterlibatan orang tua dalam perawatan fisik maupun emosi. Pemberian informasi tentang respons perilaku normal anak saat hospitalisasi dapat meningkatkan kepercayaan diri orang tua dan menurunkan stres dan kecemasan orang tua (Cooper et al., 2007) (Wong et al., 2009). Penelitian Aeni (2018) menunjukkan bahwa kemampuan keluarga dalam upaya mengatasi ansietas melalui terapi generalis asnsietas yang telah diberikan didapatkan hasil pada saat 
pretes mean 9,32 (SD 5,53) sedangkan pada saat post test 11,28 mean (SD 5,61) dengan demikian didapatkan nilai $\mathrm{p}=$ value 0,002 , yang menunjukan bahwa adanya perubahan kemampuan keluarga dalam mengatasi ansietas melalui terapi generalis ansietas tersebut (Aeni \& Pradarajati, 2018).

Hasil penelitian Rustina Y dkk (2014) didapatkan nilai $\mathrm{p}$ value $\leq 0,05$ hal ini menunjukkan bahwa program pemberdayaan keluarga efektif dalam meningkatkan pengetahuan ibu serta status imunisasi meningkat pada kelompok intervensi dengan implikasi pada BBLR yang prematur terus menerus dihadapkan pada berbagai masalah kesehatan sehingga dapat dicegah dengan memberdayakan orang tua (Rustina, Nursasi, Budiati, Syahreni, \& Fitriyani, 2014).

Penelitian Rustina sejalan dengan penelitian yang dilakukan oleh Yugystiowati tentang penerapan Family Centered -Care (FCC) sebagai program keberhasilan perawatan bayi prematur, dimana hasil penelitian menunjukkan bahwa terdapat perbedaan yang significant tingkat pengetahuan dan sikap sebelum dan sesudah dilakukan intervensi pada kelompok kontrol dan kelompok perlakuan di RSUD Saras Husada Purworejo pada bulan Oktober-November 2014, sehingga peneliti menyarankan agar pendidikan kesehatan pada orangtua bayi prematur dengan perawatan berfokus pada keluarga (FCC) sebaiknya dilakukan secara berkelanjutan sehingga dapat mengubah perilaku orangtua dalam merawat bayi prematur (Yugistyowati \& Tinggi Ilmu Kesehatan Alma Ata Yogyakarta Jalan Ringroad Barat Daya No, 2015).

\section{SIMPULAN}

Terdapat perbedaan tingkat ansietas orangtua yang mempunyai BBLR sebelum dan sesudah pemberdayaan orangtua (parent empowerment).

\section{DAFTAR PUSTAKA}

Aeni, Q., \& Pradarajati, P. (2018). Pengaruh Pemberian Terapi Generalis Dalam Mengatasi Ansietas Keluarga Pasien Hemodialisa. Jurnal Ilmu Keperawatan Jiwa, Vol 1 ,No. Retrieved From Http://Jurnal.Ppnijateng.Org/Index.Php/ Jikj/Article/View/152

Cleveland, L. M. (2008). Parenting In The Neonatal Intensive Care Unit. Journal
Of Obstetric, Gynecologic \& Neonatal Nursing, 37(6), 666-691. Https://Doi.Org/10.1111/J.15526909.2008.00288.X

Cooper, L. G., Gooding, J. S., Gallagher, J., Sternesky, L., Ledsky, R., \& Berns, S. D. (2007). Impact Of A FamilyCentered Care Initiative On Nicu Care, Staff And Families. Journal of Perinatology, 27(S2), S32-S37. Https://Doi.Org/10.1038/Sj.Jp.7211840

Departemen Kesehatan R.I. (2008). Laporan Hasil Riset Kesehatan Dasar (Riskesdas) Nasional 2007. Jakarta.

Dyna Apryani. (2013). Hubungan Yang Signifikanantara Lama Rawat (Hospitalisasi) Dengankecemasan Orang Tuadiruanganak Rsud Cianjur. Jks, 8(2). Retrieved From Http://Dx.Doi.Org/10.20884/1.Jks.2013. 8.2.47

Girsang, M. (2009). Pola Perawatan Bayi Berat Lahir Rendah Di Rumah Sakit Dan Di Rumah Dan Hal-Hal Yang Mempengaruhinya. Fik Ui. Retrieved From

Http://Digilib.Ui.Ac.Id/Opac/Themes/Li bri2/Detail.Jsp?Id=

$124600 \&$ Lokasi=Lokal

Mundy, C. A. (2010). Assessment Of Family Needs In Neonatal Intensive Care Units. American Journal of Critical Care, 19(2), 156-163. Https://Doi.Org/10.4037/Ajcc2010130

Padila, P., Amin, M., \& Rizki, R. (2018). Pengalaman Ibu Dalam Merawat Bayi Preterm Yang Pernah Dirawat Di Ruang Neonatus Intensive Care Unit Kota Bengkulu. Jurnal Keperawatan Silampari, 1(2), 1-16. Https://Doi.Org/10.31539/Jks.V1i2.82

Reeder, S. J., \& Griffin, K. (2011). Keperawatan Maternitas: Kesehatan Wanita, Bayi \& Keluarga. Jakarta: Egc.

Rita Magdalena Br. Tarigan, Restuning Widiasih, E. (2008). Pengetahuan Ibu Tentang Penatalaksanaan Perawatan Bayi Bblr Di Rumah Di Rskia Kota Bandung. Fakultas Ilmu Keperawatan Universitas Padjadjaran, 1-15. 
Rustina, Y., Nursasi, A. Y., Budiati, T., Syahreni, E., \& Fitriyani, P. (2014). The Influence Of Family Empowerment On The Health Status Of Low Birth Weight Infant In Jakarta. Makara Journal Of Health Research, 18(1). Https://Doi.Org/10.7454/Msk.V18i1.308 9

Surasmi. (2003). Perawatan Bayi Resiko Tinggi. Jakarta: Egc.

Suyami. (2013). Pengaruh Edukasi Dalam Perencanaan Pulang Terhadap Tingkat Kecemasan Dan Tingkat Efikasi Diri Ibu Dalam Merawat Bblr. Retrieved From

Lib.Ui.Ac.Id/File?File=Pdf/Abstrak20335906.Pdf\%0a\%0a

Wahyu Hendiyanto, A. (2014). Tingkat Kecemasan Ibu Yang Mempunyai Bayi Bblr Di Ruang Prinatologi Rsud Harjono. Retrieved From Http://Www.Onesearch.Id/Record/Ios28 57.599/Details

Wong, D. L., Hockenberry-Eaton, M., Wilson, D., Winkelstein, M. L., \& Schwartz, P. (2009). Buku Ajar Keperawatan Pediatrik Wong. In Volume 1. Https://Doi.Org/10.1167/Iovs.13-13688

Yugistyowati, A., \& Tinggi Ilmu Kesehatan Alma Ata Yogyakarta Jalan Ringroad Barat Daya No, S. (2015). Penerapan Family Centered-Care (Fcc) Sebagai Program Keberhasilan Perawatan Bayi Prematur Aplication Of Family Centered Care (Fcc) As Premature Baby Treatment. Jurnal Kesehatan Al-Irsyad (Jka), Vii(1). 